\title{
Utilization of Family Planning Contraceptives among Women in the Coastal Area of South Buru District, Maluku, 2017
}

\author{
Christiana Rialine Titaley*, Ninik Sallatalohy
}

Faculty of Medicine, Pattimura University, Poka Campus, Ambon

\begin{abstract}
Maluku Province is one among provinces in Indonesia with a contraceptive prevalence rate (CPR) lower than the national average. This study aimed to examine factors associated with the utilization of family planning contraceptives among women of reproductive age living in the coastal area of South Buru District, Maluku, Indonesia. Data were derived from a household health survey conducted in five subdistricts in South Buru, e.g., Namrole, Leksula, Waesama, Kapala Madan and Ambalau Subdistricts on November 2017 by the Faculty of Medicine, Pattimura University in Ambon. Information on contraceptive use were collected from 390 married women aged 20 - 49 years. Bivariate and multivariate logistic regression analysis were employed to examine the factors associated with utilization of family planning contraceptives. This study found a low rate of utilization of family planning contraceptives (38.5\%). The odds of utilization modern contraceptive significantly reduced among women living in Ambalau and Leksula Subdistricts, aged 41 - 49 years, those who intend to have more number of children, and with a low level of knowledge about family planning contraceptive methods.
\end{abstract}

Keywords: coastal area, contraceptives, family planning

\section{Introduction}

Although Indonesia has long been acknowledged as one of most successful countries in implementing family planning programs, the country has faced challenges in improving its contraceptive prevalence rate $(\mathrm{CPR})$ in the last decade.1,2 The use of long acting and permanent methods of contraceptives, which are more effective and efficient than short acting methods, has been consistently low for years. 2,3

Data from the 2012 Indonesia Demographic and Health Survey show that Maluku is one of the 33 provinces in Indonesia whose CPR among married women of reproductive age was lower $(40.4 \%)$ than the national average $(57.9 \%){ }^{2}$ This finding is supported by the 2013 data from the Ministry of Health of Republic of Indonesia reporting that only $38 \%$ of married women of reproductive age in Maluku used modern contraceptives. ${ }^{4}$ Although the CPR in Maluku increased to $69 \%$ in 2016, the rate was still lower than the national average (75\%). ${ }^{5}$ In 2017, the Provincial Health Office of Maluku reported that the CPR in the province was only at $49.74 \%$ and two districts with the lowest CPR were the district of Southwest Maluku (7.28\%) and South Buru

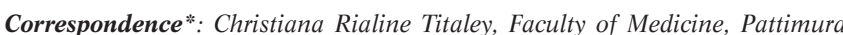
University, Ir. M. Putuhena street, Poka Campus, Ambon, E-mail: christiana_rialine@yahoo.com, Phone: +6282123067572

\section{$(14.7 \%)^{6}$}

Previous literature shows several factors associated with non-utilization of modern family planning contraceptives. ${ }^{7,8}$ These factors includes women's low level of education, 9,10 lack of knowledge about family planning, ${ }^{7,11}$ side effects of contraceptive methods,, 12 religion, ${ }^{7}$ husband's support, ${ }^{11,13}$ availability and accessibility of family planning services as well as skills of providers. ${ }^{7,8}$ This finding indicates that different interventions could be carried out to improve the uptake of family planning services. Therefore, studies to examine determinants of family planning contraceptive use are still required to improve utilization of modern contraceptives in Maluku.

In 2017, the Faculty of Medicine, Pattimura University that is the only faculty of medicine located in Ambon, the capital city of Maluku Province conducted a household health survey to examine the pattern of diseases among communities living in the coastal areas of South Buru District in Maluku. One of information collected in this survey was the utilization of family planning contraceptives among married women of reproductive age. Using this available data, this study 
analyzed factors associated with the utilization of family planning contraceptive methods by women living in the coastal area of South Buru District. An understanding of these underlying factors, is expected to provide additional insights to design supportive interventions, not only in South Buru, but also in other parts of Maluku.

\section{Method}

This analysis used data derived from a household health survey carried out in five subdistricts of South Buru District, Maluku, namely Namrole, Leksula, Waesama, Kapala Madan and Ambalau Subdisricts. According to data from the Provincial Health Office of Maluku, South Buru District was one of districts with lowest CPR in the province. ${ }^{6}$ This cross-sectional survey was conducted on November 2017 by the Faculty of Medicine, Pattimura University, Ambon.

This survey used a modified Expanded Program on Immunization (EPI) Sampling Method, ${ }^{14}$ using 30 clusters (villages) with sub-village as the sub-cluster. The total sample size of this study was 900 respondents, which was calculated using the sample-calculating formula for descriptive research, with $\alpha=5 \%$, $p$-value = $50 \%$ (to reach maximum value), $d=0.1$ and deff $=2$.

Clusters (villages) were selected by using the proportionate probability to size (PPS) method, which means that the probability of selecting a cluster was proportional to its size. Subclusters (sub-villages) were selected using simple random sampling method. In each sub-village, interviewers conducted house-to-house visits until information was collected from 30 respondents. Houses in each sub-village were selected randomly by choosing the road direction, drawing the location of houses in the selected direction, followed by the selection of the first house randomly. The second house was the house whose front door is the closest to the first house's front door. A similar method was used for the third house, and so on. For this analysis, information from 390 married and nonpregnant women aged 20 - 49 years interviewed was used.

Data were collected by trained interviewers who were students and medical doctors who graduated from the Faculty of Medicine, Pattimura University. A two-day training program was held in Ambon, prior to data collection and covered different aspects of the survey, including a try-out session with the local community in the Ambon area.

Household interviews were conducted using a structured questionnaire containing various topics, namely identity of respondents, household socioeconomic background, status of food security, smoking habits, history of family's disease, history of respondent's disease, history of reproduction and use of contraception (for women aged 20 - 49 years), history of medical treatment, history of traditional drug use, physical examination, and general conditions. For this analysis, variables were derived from two main sections, e.g., household socio-economic background and the records of reproduction and the use of contraceptives (specifically for women aged 20 - 49 years).

The analyzed dependent variable was the use of contraceptive (using vs. not using) and wasconstructed from two questions: (1) "Is the mother currently or has been using a contraceptive method within a month to delay or limit pregnancy?" and (2) "What is the type of contraceptive used?". If the respondent answered "yes" to the first question and reported using any type of modern contraceptives (e.g., condom, pill, injectable, intrauterine contraceptive device, implant, tubectomy or emergency contraception) in the second question, then the answer would be coded as "1" (yes, using contraceptive method). If respondent answered " no" to the first question, or answered "yes " to the first question and then answered traditional contraceptive methods to the second question, then the answer was coded as " 0 " (not using any contraceptive).

The potential predictors of family planning use were classified into three levels, namely environment, household, and individual characteristics. At the environment level, a variable indicated the subdistrict where the respondent lived. At the household level, two variables were included, e.g., household wealth index and the number of people living in the house. With the use of principal component analysis (PCA), ${ }^{15}$ household wealth index was constructed utilizing household's facilities and assets e.g., ownership of bicycle, motorcycle, non-engine boat, engine boat, television, air conditioner, water heater, $12 \mathrm{~kg}$ of liquified petroleum gas (LPG), fridge, car, toilet, fuel for cooking, and source of drinking water. This index was to rank all households and further divided them into five groups (quintiles) e.g., poorest, poor, middle, rich and richest categories of households.

At the individual level, there were six variables used including age of respondent, highest educational attainments, respondent's occupation, desire for pregnancy, the number of children alive, and knowledge of family planning. Knowledge of family planning was constructed from three components, that were knowing the suitable contraceptive method to delay pregnancy (e.g., all contraceptive methods, such as condom, pills, injectables, emergency, implant, IUD (Intauterine Device), tubectomy and vasectomy), knowing the contraceptive method to limit pregnancy (e.g., implant, IUD, tubectomy and vasectomy), and knowing the duration of long acting and permanent methods (LAPMs) of contraception (implant, IUD, tubectomy and vasectomy). A score of " 1 " or " 0 " was assigned when the respondent answered the question correctly or 
incorrectly, respectively. The total scores of all the three components were further summed to obtain the total score, ranging from "0" (answering all questions incorrectly), to "12" (answering all questions correctly). Finally, the scores were divided into categories of low (less than median) and high level of knowledge (equal to median or above).

In data analysis, frequency distribution tables were first developed. Second, data were analyzed using contingency tables to examine the distribution of all variables across the outcome variable. Third, bivariate logistic regression was conducted to calculate the unadjusted odds ratio (OR) of all potential predictors for utilization of family planning contraceptives without controlling for other covariates. Fourth, multivariate logistic regression was carried out to assess the association between potential predictors and utilization of family planning contraceptive, after adjusting for other variables. The association was mirrored by the adjusted OR (aOR). In multivariate analysis, backward elimination was applied to eliminate factors that are not significantly related to the use of contraceptives with a significance level of 0.05 . All analyses were performed using STATA/MP 15.1 (serial number: 501506348062).

Ethics approval for the study was obtained from the Ethics Committee of the Faculty of Medicine, Pattimura

Table 1. Distribution of Respondents by Use of Contraceptive, South Buru District, Maluku Province, 2017

\begin{tabular}{|c|c|c|c|c|c|c|c|}
\hline \multirow{3}{*}{ Variable } & \multirow{3}{*}{ Category } & \multirow{3}{*}{$\mathbf{N}$} & \multirow{3}{*}{$\%$} & \multicolumn{4}{|c|}{ Use of Contraceptive } \\
\hline & & & & \multicolumn{2}{|c|}{ Yes } & \multicolumn{2}{|c|}{ No } \\
\hline & & & & $\mathbf{n}$ & $\%$ & $\mathbf{n}$ & $\%$ \\
\hline \multirow[t]{6}{*}{ Environmental factor } & Subdistrict & & & & & & \\
\hline & Kapala Madan & 70 & 17.95 & 41 & 58.6 & 29 & 41.4 \\
\hline & Namrole & 121 & 31.03 & 49 & 40.5 & 72 & 59.5 \\
\hline & Ambalau & 47 & 12.11 & 5 & 10.6 & 42 & 89.4 \\
\hline & Leksula & 80 & 20.51 & 22 & 27.5 & 58 & 72.5 \\
\hline & Waesama & 72 & 18.5 & 40 & 55.6 & 32 & 44.4 \\
\hline \multirow[t]{9}{*}{ Household factor } & Household wealth index & & & & & & \\
\hline & Poorest & 86 & 22.0 & 29 & 33.7 & 57 & 66.3 \\
\hline & Poor & 73 & 18.5 & 27 & 37.5 & 45 & 62.5 \\
\hline & Middle & 76 & 19.5 & 30 & 39.5 & 46 & 60.5 \\
\hline & Rich & 78 & 20 & 34 & 43.6 & 44 & 56.4 \\
\hline & Richest & 78 & 20 & 29 & 37.2 & 49 & 62.8 \\
\hline & The number of household members & & & & & & \\
\hline & $\leq 5$ people & 139 & 35.6 & 50 & 36.0 & 89 & 64.0 \\
\hline & $>5$ people & 251 & 64.4 & 99 & 39.4 & 152 & 60.6 \\
\hline \multirow[t]{25}{*}{ Individual factor } & Educational attainment & & & & & & \\
\hline & No schooling/ incomplete primary school & 38 & 9.7 & 12 & 31.6 & 26 & 68.4 \\
\hline & Completed primary school & 117 & 30 & 44 & 36.8 & 73 & 63.2 \\
\hline & Completed junior high school & 69 & 17.7 & 36 & 47.8 & 33 & 52.2 \\
\hline & Completed senior high school & 106 & 27.2 & 35 & 33.0 & 71 & 67.0 \\
\hline & Academy/ university & 60 & 15.4 & 23 & 31.7 & 37 & 68.3 \\
\hline & Occupation & & & & & & \\
\hline & Housewife & 202 & 51.8 & 71 & 35.2 & 131 & 64.9 \\
\hline & Farmer/ fisherman/ labor & 122 & 31.3 & 52 & 42.6 & 70 & 57.4 \\
\hline & Civil servant/ teacher/ honorarium-based & 50 & 12.8 & 20 & 40.0 & 30 & 60.0 \\
\hline & Other & 16 & 4.1 & 6 & 37.5 & 10 & 62.5 \\
\hline & Age (in years) & & & & & & \\
\hline & $21-30$ & 110 & 28.42 & 49 & 44.5 & 61 & 55.5 \\
\hline & $31-40$ & 175 & 42.5 & 82 & 53.1 & 93 & 46.9 \\
\hline & $41-49$ & 102 & 26.4 & 18 & 17.6 & 84 & 82.4 \\
\hline & Desire for pregnancy & & & & & & \\
\hline & No/ cannot get pregnant & 236 & 60.5 & 86 & 36.4 & 150 & 63.6 \\
\hline & Yes, later & 124 & 31.8 & 60 & 48.4 & 64 & 51.6 \\
\hline & Yes & 30 & 7.8 & 3 & 10.0 & 27 & 90.0 \\
\hline & The number of children alive & & & & & & \\
\hline & $\leq 2$ & 145 & 37.18 & 53 & 36.6 & 92 & 63.4 \\
\hline & $>2$ & 245 & 62.82 & 96 & 39.2 & 149 & 60.8 \\
\hline & Knowledge of family planning 1 ) & & & & & & \\
\hline & High & 128 & 32.8 & 66 & 51.6 & 62 & 48.4 \\
\hline & Low & 262 & 67.2 & 83 & 31.7 & 179 & 68.3 \\
\hline
\end{tabular}

Note:

1) Knowledge of family planning consists of knowledge of the suitable contraceptive method to delay pregnancy, knowledge of the suitable contraceptive method to limit pregnancy, and knowledge of the duration of long acting and permanent methods. A high level of knowledge indicates a score of equal or above the median distribution and low level of knowledge indicates a score less than the median. 
University, Ambon (Ref No. 184/FKKOM.ETIK/VIII/2017). The research permit was obtained from the Maluku Provincial Government and the administrative leaders at study sites. Prior to the interview, the interviewers obtained signed informed consent from the respondents regarding their willingness to participate in the study.

\section{Results}

Of the 390 married and nonpregnant women of reproductive age (20 - 49 years) from South Buru District interviewed in this survey, only $38.5 \%(n=149)$ used modern contraceptives. The short-acting method was the dominant contraceptive method. Around $83 \%$ of contraceptive users preferred injectable methods, and only slightly over 10\% used LAPMs (implant, tubectomy and IUD).

The frequency distribution of respondents involved in this analysis is shown in Table 1. More than $42 \%$ respondents graduated from senior high school or higher; and more than half were housewives. Notably, more than $60 \%$ of respondents intended to limit their pregnancy. The study also found that. approximately, two-thirds of respondents had a low level of knowledge (less than the median score).

The lowest proportion of respondents using modern contraceptives was found in Ambalau Subdistrict $(10.6 \%)$ (Table 1). Respondents aged 41 years and older

Table 2. Results of Bivariate Analysis for Factors Associated with Utilization of Modern Contraceptive Methods in Coastal Community in South Buru District, Maluku Province, 2017

\begin{tabular}{|c|c|c|c|c|}
\hline Variable & Category & OR & $95 \% \mathrm{CI}$ & p-value \\
\hline \multirow[t]{6}{*}{ Environmental factor } & Subdistrict & & & \\
\hline & Kapala Madan & 1.00 & & \\
\hline & Namrole & 0.48 & $0.26-0.88$ & 0.017 \\
\hline & Ambalau & 0.08 & $0.03-0.24$ & $<0.001$ \\
\hline & Leksula & 0.27 & $0.14-0.53$ & $<0.001$ \\
\hline & Waesama & 0.57 & $0.29-1.10$ & 0.093 \\
\hline \multirow[t]{9}{*}{ Household factor } & Household wealth index & & & \\
\hline & Poorest & 1.00 & & \\
\hline & Poor & 1.18 & $0.61-2.27$ & 0.621 \\
\hline & Middle & 1.28 & $0.67-2.43$ & 0.448 \\
\hline & Rich & 1.52 & $0.81-2.86$ & 0.195 \\
\hline & Richest & 1.16 & $0.61-2.21$ & 0.644 \\
\hline & Number of household members & & & \\
\hline & $\leq 5$ people & 1.00 & & \\
\hline & $>5$ people & 1.16 & $0.75-1.78$ & 0.499 \\
\hline \multirow[t]{25}{*}{ Individual factor } & Educational attainment & & & \\
\hline & No schooling/ incomplete primary school & 1.00 & & \\
\hline & Completed primary school & 1.26 & $0.60-2.85$ & 0.563 \\
\hline & Completed junior high school & 2.36 & $1.16-6.11$ & 0.043 \\
\hline & Completed senior high school & 1.07 & $0.48-2.36$ & 0.871 \\
\hline & Academy/ university & 1.35 & $0.57-3.18$ & 0.497 \\
\hline & Occupation & & & \\
\hline & Housewife & 1.00 & & \\
\hline & Farmer/ fisherman/ labor & 1.37 & $0.86-2.17$ & 0.180 \\
\hline & Civil servant/ teacher/ honorarium-based & 1.23 & $0.65-2.32$ & 0.523 \\
\hline & Other & 1.10 & $0.39-3.17$ & 0.850 \\
\hline & Age (in years) & & & \\
\hline & $21-30$ & 1.00 & & \\
\hline & $31-40$ & 1.10 & $0.68-1.77$ & 0.703 \\
\hline & $41-49$ & 0.27 & $0.14-0.50$ & $<0.001$ \\
\hline & Desire for pregnancy & & & \\
\hline & No/cannot get pregnant & 1.00 & & \\
\hline & Yes, later & 1.64 & $1.05-2.54$ & 0.029 \\
\hline & Yes & 0.19 & $0.06-0.66$ & 0.008 \\
\hline & The number of children alive & & & \\
\hline & $\leq 2$ & 1.00 & & \\
\hline & $>2$ & 1.12 & $0.73-1.71$ & 0.605 \\
\hline & Knowledge of family planning1) & & & \\
\hline & High & 1.00 & & \\
\hline & Low & 0.44 & $0.28-0.67$ & $<0.001$ \\
\hline
\end{tabular}

Note:

$\mathrm{OR}=$ odds ratio; $\mathrm{CI}=$ confidence interval; ${ }^{1}$ Knowledge of family planning consists of (a) knowledge of the suitable contraceptive method to delay pregnancy; (b) knowledge about the suitable contraceptive method to limit pregnancy; and (c) knowledge about the duration of long acting and permanent methods (LAPMs). A high level of knowledge indicates a score of equal or above the median distribution and low level of knowledge indicates a score less than the median. 
had the lowest percentage of contraceptive use (17.6\%). The proportion of respondents using family planning contraceptives was lower among respondents with a low level of knowledge $(31.7 \%)$ than those with a high level of knowledge (51.6\%).

From bivariate analysis (Table 2), factors associated with the use of family planning services were subdistrict, respondent's age, desire for pregnancy, and knowledge of contraceptive methods. However, in this bivariate model, only the relationship between each potential variable and study outcome was examined, without controlling for other covariates.

Multivariate logistic regression analyses (Table 3) indicate that the respondents from Ambalau (aOR = $0.11,95 \% \mathrm{CI}=0.03-0.31$, -value $<0.001)$ and Leksula $(\mathrm{aOR}=0.32,95 \% \mathrm{CI}=0.14-0.62, \mathrm{p}$-value $=0.002)$ were less likely to use contraceptives than those living in Kapala Madan Subdistrict. Respondents aged 41 - 49 years were $80 \%$ less likely to use modern contraceptives $(\mathrm{aOR}=0.21,95 \% \mathrm{CI}=0.10-0.46, \mathrm{p}$-value $<0.001)$ than those aged 21 - 30 years. The likelihood of using contraceptive among respondents intending to get pregnant reduced significantly $(\mathrm{aOR}=0.09,95 \% \mathrm{CI}=$ 0.02 - 0.34, p-value < 0.001) compared with those who would like to limit pregnancy. The important role of knowledge in family planning contraceptive use was clearly shown in the analysis. The odds of contraceptive use among respondents who had a low level of knowledge about contraceptive was almost $60 \%$ less than the odds of contraceptive use among respondents with a high level of knowledge $(\mathrm{aOR}=0.44,95 \% \mathrm{CI}=$ 0.27 - 0.72, $\mathrm{p}$-value $=0.001$ ).

\section{Discussion}

This study found a low uptake of family planning contraceptive methods among women living in the coastal area of South Buru District in 2017. The use of contraceptives was dominated by non-Long Acting / Permanent Methods (non-LAPM) of contraceptives, particularly the injectable methods. The use of contraceptives reduced significantly among women living in Ambalau and Leksula Subdistrict, women aged 41 49 years, those intending to have more children, and those with a low level of knowledge of family planning contraceptive methods. These results might be used to assist policy and decision makers to design and implement effective and evidence-based interventions to improve the use of contraceptive methods in South Buru District.

The area where respondents lived had a significant association with the uptake of family planning services. Ambalau is an island separated from the main island of Buru, and access to it is challenging during certain times beacuse sea access is the only entry point to this area. Given that the limited access and availability of family planning services could negatively affect the utilization of family planning services, as reported in other studies, ${ }^{7-}$ 9 this issue should be taken into account by both service providers and users. However, the local condition might become a strong motivation for providers to promote the

Table 3. Results of Multivariate Analyses for Factors Associated with Utilization of Modern Contraceptive Methods in Coastal Community in South Buru District, Maluku Province, 20171)

\begin{tabular}{|c|c|c|c|c|}
\hline Variable & Category & aOR & $95 \% \mathrm{CI}$ & p-value \\
\hline \multirow[t]{6}{*}{ Environmental factor } & Subdistrict & & & \\
\hline & Kapala Madan & 1.00 & & \\
\hline & Namrole & 0.48 & $0.26-0.88$ & 0.017 \\
\hline & Ambalau & 0.08 & $0.03-0.24$ & $<0.001$ \\
\hline & Leksula & 0.27 & $0.14-0.53$ & $<0.001$ \\
\hline & Waesama & 0.57 & $0.29-1.10$ & 0.093 \\
\hline \multirow[t]{11}{*}{ Individual factor } & Age (in years) & & & \\
\hline & $21-30$ & 1.00 & & \\
\hline & $31-40$ & 1.10 & $0.68-1.77$ & 0.703 \\
\hline & $41-49$ & 0.27 & $0.14-0.50$ & $<0.001$ \\
\hline & Desire for pregnancy & & & \\
\hline & No/cannot get pregnant & 1.00 & & \\
\hline & Yes, later & 1.64 & $1.05-2.54$ & 0.029 \\
\hline & Yes & 0.19 & $0.06-0.66$ & 0.008 \\
\hline & Knowledge of family planning2) & & & \\
\hline & High & 1.00 & & \\
\hline & Low & 0.44 & $0.28-0.67$ & $<0.001$ \\
\hline
\end{tabular}

Note:

aOR = adjusted Odds Ratio; $\mathrm{CI}=$ Confidence Interval; ${ }^{1}$ Backward elimination method was used to retain only variables significantly related to the study outcome (significance level of 0.05 was applied); ${ }^{2}$ Knowledge of family planning consists of (a) knowledge about the suitable contraceptive method to delay pregnancy; (b) knowledge about the suitable contraceptive method to limit pregnancy; and (c) knowledge about the duration of long-acting and permanent methods. A high level of knowledge indicates a score of equal or above the median distribution and a low level of knowledge indicates a score of less than the median. 
use of LAPM particularly among those intending to delay or even limit pregnancy. To improve LAPM use, several factors should be considerated, such as improving the knowledge and skills of providers; demanding creation within the community, addressing misconceptions on LAPM; and ensuring the availability of supplies and equipment required for LAPM services. ${ }^{16}$

As shown in previous literature, age in this study was a significant predictor of contraceptive use. ${ }^{17,18}$ Women aged 41 - 49 years had a reduced likelihood of using contraceptive methods. Although they were still within the reproductive age range, some women might think that they no longer need any contraceptive methods as they become less fecund. ${ }^{17}$ Strengthening family planning education programs is thereby still important, not only for young mothers, but also for those aged 40 years and older. In adition, health workers should also be encouraged to use every contact opportunity to improve the awareness of women and their spouses awareness of reproductive health and family planning programs.

The study finding emphasized the role of knowledge of family planning contraceptives in the community of South Buru District. This condition supports findings from other studies regarding the importance of improving women's knowledge to increase the uptake of family planning methods. ${ }^{7,11,19}$ Activities to enhance community knowledge on family planning are still crucial. Different awareness-raising interventions could be implemented because they are reportedly effective for demand creation. $8,16,20$ The use of information, education and communication materials, such as banners or posters on family planning issues, in addition to behavior change communication strategies were reportedly beneficial in improving knowledge of family planning services. ${ }^{8,21}$ A study showed that a presentation on family planning at different social events, such as community meetings of women, men, and youth, could improve utilization. ${ }^{22}$

Apart from group-based interventions, interpersonal communication plays a key role. A study in Uganda showed that counseling programs that involve letting women see and touch family planning contraceptive, or encouraging health workers to use all contact opportunities to counsel women about family planning, such as during antenatal or postnatal care, could beneficially improve family planning uptake. ${ }^{23}$ Nevertheless, providers should have sufficient knowledge and skills to conduct effective counseling sessions. A qualitative study from other areas of Indonesia showed that many health workers and family planning providers had not attended any counseling training programs. ${ }^{24}$ Considering the limited available training programs, onthe-job training might be an alternative and will help increase the number of providers trained to provide good-quality services.

Previous literature showed the important role of partners in family planning programs. $9,13,25$ Women who discuss contraceptive methods with their spouse are more likely to use modern contraceptives. Encouragement and, most essentially, approval from their husband are highly valued by women. ${ }^{9}$ Couples counseling, promotional activities with men's groups or mass media campaigns could be conducted to improve the husband's or other family members' awareness. ${ }^{26}$

Intersectoral collaboration is also a key factor in family planning programs, particularly between government and private sectors. ${ }^{27}$ Private sectors could assist in developing effective promotional and counseling materials tailored to the local condition and culture, facilitating training programs for providers, or expanding family planning services, particularly LAPM, during specific events.

This study has some strengths and limitations. As the study was designed to represent the coastal area of South Buru, the results could be used to plan interventions to improve the uptake of family planning services. The sample size used in this study was adequate to examine different potential predictors of family planning use, starting from the environment, household, to the individual-level factors. However, some limitations should also be noted. Given that this was a crosssectional survey, the analysis could not show any causeand-effect relationship between the variables. The information provided by respondents was also not validated, as it was merely based on the women's recall ability. Some variables that might be potentially related to the low utilization of family planning services were not examined because they are unavailable in the dataset. These variables include support from the husband and other family members, the quality of family planning services, and the availability of contraceptives in the area. Nonetheless, these limitations are unlikely to reduce the validity of the analysis.

\section{Conclusion}

Overall, the use of family planning services in women living in the coastal area of South Buru District remains low and is highly dominated by non-LAPMs, particularly injectable methods. The study finds several significant predictors for family planning, including the subdistrict where the women live, age, fertility intention, and women's knowledge of family planning contraceptives.

\section{Recommendation}

Efforts to encourage utilization of LAPM services will be beneficial for communities in areas with limited access to family planning services, or irregular and frequently 
disrupted contraceptive supplies. Health promotion programs and awareness raising activities are required to improve the community's knowledge of family planning, targeting not only the youth, but also women aged 40 years and older, as well as women's spouses and other family members. Activities to improve providers' knowledge and counseling skills are also essential to support the demand creation. Intersectoral collaboration should be encouraged to assist the local government of South Buru District to improve access to and the quality and quantity of family planning services.

\section{Abbreviations \\ CPR: Contraceptive Prevalence Rate; LAPMs: Long Acting and Permanent Methods; EPI: Expanded Program on Immunization; PPS: Proportionate probability to size; PCA: Principal Component Analysis; LPG: Liquified Petroleum Gas; IUD: Intrauterine Device; aOR: adjusted Odd Ratio.}

\section{Ethics Approval and Consent to Participate}

Ethics approval for the study was obtained from the Ethics Committee of the Faculty of Medicine, Pattimura University, Ambon (Ref No. 184/FK-KOM.ETIK/VIII/2017). The research permit was obtained from the Provincial Government of Maluku Province, as well as the administrative leaders from study sites. Prior to the interview, the interviewers obtained signed informed consent from the respondents regarding their willingness to participate in the study.

\section{Competing Interest}

Author declares that there are no significant competing financial, professional, or personal interests that might have affected the performance or presentation of the work described in this manuscript.

\section{Availability of Data and Materials}

The data that support the findings of this study are available from Faculty of Medicine, Pattimura University, Ambon but restrictions apply to the availability of these data, which were used under license for the current study, and so are not publicly available. Data are however available from the authors upon reasonable request and with permission of Faculty of Medicine, Pattimura University, Ambon.

\section{Authors' Contribution}

Christiana Rialine Titaley designed the study and performed data analysis; Christiana Rialine Titaley and Ninik Sallatalohy prepared, reviewed and revised the manuscript. Both authors read and approved the final manuscript.

\section{Acknowledgment}

We would like to express our gratitude to the Dean and all staff of Faculty of Medicine, Pattimura University, who have supported this study enormously. We also would like to sincerely thank the Government of Maluku Province, local Government of South Buru District and leaders in all sub-districts, villages and hamlets for their supports. We sincerely thank the community of South Buru District, particularly our respondents in the coastal areas, who were willing to involve in the study. This study cannot be accomplished without the commitment and hard work of the entire data collection team of Faculty of Medicine, Pattimura University in Ambon.

\section{References}

1. Hayes A. The status of family planning and reproductive health in Indonesia: a story of success and fragmentation. In: family planning in Asia and the Pacific: addressing the challenges. Selangor, Malaysia: International Council on Management of Population Programmes. 2012; 225-41.

2. Statistics Indonesia, National Family Planning Coordinating Board, Ministry of Health Republic of Indonesia, ORC Macro. Indonesia Demographic and Health Survey 2012. Calverton, Maryland: BPS and ORC Macro; 2013.

3. World Health Organization, Johns Hopkins Bloomberg School of Public Health/Center for Communication Programs (CCP), USAID. Family planning: a global handbook for providers Baltimore, MD; Geneva, Switzerland: CCP and WHO; 2011.

4. National Institute of Health Research and Development Ministry of Health, Republic of Indonesia. Basic Health Research 2013: National Report 2013. Jakarta: National Institute of Health Research and Development, Ministry of Health, Republic of Indonesia; 2013.

5. Pusat Data dan Informasi Kementerian Kesehatan RI. Data dan Informasi: profil kesehatan Indonesia 2016. Jakarta: Pusat Data dan Informasi Kementerian Kesehatan RI; 2017.

6. Health Office of Maluku Province. Routine report of family health of Maluku Province. Ambon: Provincial Health Office of Maluku; 2017.

7. Blackstone SR, Nwaozuru U, Iwelunmor J. Factors influencing contraceptive use in sub-saharan Africa: a systematic review. International Quarterly of Community Health Education. 2017; 37(2): 79-91.

8. Mwaikambo L, Speizer IS, Schurmann A, Morgan G, Fikree F. What works in family planning interventions: a systematic review. Studies in Family Planning. 2011; 42(2): 67-82.

9. Eliason S, Awoonor-Williams JK, Eliason C, Novignon J, Nonvignon J, Aikins M. Determinants of modern family planning use among women of reproductive age in the Nkwanta District of Ghana: a case-control study. Reproductive Health. 2014; 11(1): 65.

10. Jalang'o R, Thuita F, Barasa SO, Njoroge P. Determinants of contraceptive use among postpartum women in a county hospital in rural Kenya. BMC Public Health. 2017; 17(1): 604.

11. Haider TL, Sharma M. Barriers to family planning and contraception uptake in Sub-Saharan Africa: a systematic review. International Quarterly of Community Health Education. 2013; 33(4): 403-13.

12. Apanga PA, Adam MA. Factors influencing the uptake of family planning services in the Talensi district, Ghana. Pan African Medical Journal. 2015; 20: 10.

13. Sekoni OO, Owoaje ET. Factors associated with family planning uptake among women in South West Nigeria. Contraception. 2013; 88(2): 315-6.

14. Chao LW, Szrek H, Peltzer K, Ramlagan S, Fleming P, Leite R, Magerman J, Ngwenya GB, Pereira NS, Behrman J. A comparison of EPI sampling, probability sampling, and compact segment sampling 
methods for micro and small enterprises. Journal of Development Economics. 2012; 98(1): 94-107.

15. Smits, J., Steendijk, R. Social indicators research in: the International Wealth Index. 2015; 122: 65.

16. World Health Organization. Strategies to increase use of long-acting and permanent contraception in: From Evidence to Policy: Expanding Access to Family Planning; 2012.

17. Mandiwa C, Namondwe B, Makwinja A, Zamawe C. Factors associated with contraceptive use among young women in Malawi: analysis of the 2015-16 Malawi demographic and health survey data. Contraception and Reproductive Medicine. 2018; 3: 12.

18. Godfrey EM, Chin NP, Fielding SL, Fiscella K, Dozier A. Contraceptive methods and use by women aged 35 and over: a qualitative study of perspectives. BMC Women's Health. 2011; 11: 5.

19. Titaley CR, Ariawan I, Damayanti R, Ismail A, Saputri AY, Yelda F, et al. Poor knowledge and nonuse of long-acting/permanent pethods of contraceptives in six districts in Indonesia. Asia Pacific Journal of Public Health. 2017; 29(8): 660-72.

20. Speizer IS, Corroon M, Calhoun L, Lance P, Montana L, Nanda P, Guilkey D. Demand generation activities and modern contraceptive use in urban areas of four countries: a longitudinal evaluation. Global Health: Science and Practice. 2014; (4): 410-26.

21. Krenn S, Cobb L, Babalola S, Odeku M, \& Kusemiju B. Using behavior change communication to lead a comprehensive family planning program: the Nigerian urban reproductive health initiative. Global Health: Science and Practice. 2014; 2(4): 427-43.
22. Amo-Adjei J, Mutua M, Athero S, Izugbara C, Ezeh A. Improving family planning services delivery and uptake: experiences from the "reversing the stall in fertility decline in western kenya project". BMC Research Notes. 2017; 10: 498.

23. Birungi R, Byabagambi J, Rahimzai M. Improving the quality of family planning services in Uganda: tested changes implemented in four districts of western Uganda. Published by USAID Applying Science to Strengthen and Improve Systems (ASSIST) Project. Bethesda, MD: University Research Co., LLC (URC); 2016.

24. Titaley CR, Wijayanti RU, Damayanti R, Setiawan AD, Dadun, Dachlia D, et al. Increasing the uptake of long-acting and permanent methods of family planning: a qualitative study with village midwives in East Java and Nusa Tenggara Barat Provinces, Indonesia. Midwifery. 2017; 53: 55-62.

25. Mekonnen W, Worku A. Determinants of low family planning use and high unmet need in Butajira District, South Central Ethiopia. Reproductive Health. 2011; 8: 37.

26. US Agency for International Development, Family Health International, Progress. Increasing men's engagement to improve family planning programs in South Asia North Carolina USA: FHI. 2012.

27. Munroe E, Hayes B, Taft J. Private-sector social franchising to accelerate family planning access, choice, and quality: results from marie stopes international. Global Health: Science and Practice. 2015; 3 (2): 195-208. 